\title{
SISTEM PENDUKUNG KEPUTUSAN PENERIMAAN KARYAWAN MENGGUNAKAN METODE SAW PADA CV. GREEN ADVERTISING
}

\author{
Rinianty ${ }^{1}$ \\ Sukardi $^{2}$ \\ 1,2Jurusan Teknik Informatika, STMIK Adhi Guna \\ E-mail: ${ }^{1}$ rinistmikadhiguna@gmail.com, ${ }^{2}$ sukarvi@gmail.com
}

Diterima: 2 Januari 2018/ Disetujui : 17 Januari 2018

\begin{abstract}
$C V$. Green Advertising is one of the businesses engaged in typing and printing services. In supporting the future of the company needed quality human resources. The selection process of employee acceptance on Green Advertising is still done manually, sorting the file of applicants and then compare with the predefined criteria. This takes a long time to affect the efficiency of decision making. From these problems, then needed a sistem that can help the leadership of Green Advertising in the receipt of employees. In this research used decision support sistem using Simple Additive Weighting method with prototype development model. The Simple Additive Weighting method is a weighted sum method used to find the optimal alternative of a number of alternatives with certain criteria. The criteria used in the research of the employee selection decision support sistem are the last educational criteria, work experience, skill and completeness of the file. Result of research from Decision Support Support Sistem Employee use computerized sistem and manual sistemsprovide the same alternative options.
\end{abstract}

Keywords : Simple Additive Weighting, Employee Reception, Decision Support Sistem

\begin{abstract}
ABSTRAK
$C V$. Green Advertising merupakan salah satu usaha yang bergerak dalam bidang jasa pengetikan dan percetakan. Dalam menunjang masa depan perusahaan dibutuhkan sumber daya manusia yang berkualitas. Proses seleksi penerimaan karyawan pada Green Advertising masih dilakukan secara manual yakni memilah berkas pelamar kemudian membandingkan dengan kriteria yang telah ditetapkan. Hal ini membutuhkan waktu yang cukup lama sehingga berpengaruh terhadap efisiensi pengambilan keputusan.Dari masalah tersebut, maka dibutuhkan sistem yang dapat membantu pimpinan Green Advertising dalam penerimaan karyawan. Pada penelitian ini digunakan sistem pendukung keputusan menggunakan metode Simple Additive Weighting dengan model pengembangan prototype. Metode Simple Additive Weighting adalah metode penjumlahan terbobot yang digunakan untuk mencari alternatif optimal dari sejumlah alternatif dengan kriteria tertentu, Kriteria yang digunakan dalam penelitian sistem pendukung keputusan pemilihan karyawan adalah kriteria pendidikan terakhir, pengalaman kerja, keahlian dan kelengkapan berkas. Hasil penelitian dari Sistem Pendukung Keputusan Penerimaan Karyawan menggunakan sistem komputerisasi dan sistem manual memberikan pilihan alternatif yang sama.
\end{abstract}

Kata Kunci :Simple Additive Weighting, Penerimaan Karyawan, Sistem Pendukung Keputusan

\section{PENDAHULUAN}

Investasi sumber daya manusia dalam sebuah perusahaan adalah hal yang sangat penting. Dalam penyeleksian sumber daya manusia yang memiliki keahlian di bidangnya harus dikelola secara professional sehingga dapat meningkatkan mutu dan kesuksesan sebuah perusahaan. Seleksi yang tepat dalam kebutuhan sumber daya manusia diperlukan beberapa kriteria khusus. Kriteria tersebut 
biasanya telah ditetapkan oleh perusahaan dan menjadi alat patokan penilaian dari kualifikasi yang dimiliki oleh masing-masing calon karyawan yang melamar.

CV. Green Advertising merupakan salah satu usaha yang bergerak dalam bidang jasa pengetikan dan percetakandimanausaha ini membutuhkan sumber daya manusia yang berkualitas guna menunjang masa depan perusahaan. Selama ini proses seleksi penerimaan karyawan pada CV.Green Advertising masih dilakukan secara manual yakni memilah berkas-berkas pelamar dan membandingkan dengan kriteria yang telah ditetapkan. Kemudian dilanjutkan dengan proses lainnya seperti wawancara dan tes potensi. Hal ini tentunya membutuhkan waktu yang cukup lama. Oleh karena itu diperlukan suatusistemkomputerisasi yang bisa membantu pengambil keputusan dalam memberikan hasil seleksi karyawan yang efisien dan efektif.

Sistem Pendukung Keputusan (SPK) adalah salah satu sistem informasi yang dapat membantu dalam pengambilan keputusan. Metode yang dapat diterapkan pada Sistem Pendukung Keputusan yaitu Simple Additive Weighting (SAW) yang merupakan salah satu metode untuk menyelesaikan masalah multi-attribute decision making. Konsep dasar metode SAW adalah mencari penjumlahan terbobot dari rating kinerja pada setiap alternative pada semua atribut.[1]

Penerapan dalam penggunaan sistem pendukung keputusan sudah banyak dilakukan oleh beberapa peneliti. Ada beberapa penelitian sebelumnya yang relevan dan menjadi rujukan dalam penelitian ini antara lain :

Tabel 1. Penelitian lain yang relevan

\begin{tabular}{|c|c|c|c|c|}
\hline No & Peneliti/Tahun & Judul Penelitian & Metode Analisis & Hasil/Kesimpulan \\
\hline 1 & $\begin{array}{l}\text { Hermanto, } \\
\text { Nandang (2012) } \\
{[2]}\end{array}$ & $\begin{array}{l}\text { Sistem Pendukung } \\
\text { Keputusan } \\
\text { menggunakan } \\
\text { Metode Simple } \\
\text { Additive Weighting } \\
\text { (SAW) untuk } \\
\text { menentukan jurusan } \\
\text { pada SMK Bakti } \\
\text { Purwokerto }\end{array}$ & $\begin{array}{l}\text { Metode yang } \\
\text { digunakan } \\
\text { dalam penelitian } \\
\text { adalah Metode } \\
\text { fuzzy Multi- } \\
\text { Attribute } \\
\text { Decision } \\
\text { Making }\end{array}$ & $\begin{array}{l}\text { Hasil penelitian berupa } \\
\text { aplikasi web yang bias diakses } \\
\text { dimana saja oleh calon siswa } \\
\text { untuk melakukan pendaftaran } \\
\text { secara online, kemudian data } \\
\text { yang diolah untuk menentukan } \\
\text { jurusan yang tepat untuk } \\
\text { masing-masing siswa. }\end{array}$ \\
\hline 2 & $\begin{array}{l}\text { Ni Ketut Dewi } \\
\text { Ari Jayanti } \\
\text { (2016)[3] }\end{array}$ & $\begin{array}{l}\text { Implementasi } \\
\text { Metode SAW dan } \\
\text { AHP pada Sistem } \\
\text { Informasi Penilaian } \\
\text { Kinerja Dosen }\end{array}$ & $\begin{array}{l}\text { Metode yang } \\
\text { digunakan } \\
\text { dalam penelitian } \\
\text { adalah Metode } \\
\text { Simple Additive } \\
\text { Weighting } \\
\text { (SAW) dan } \\
\text { metode } \\
\text { Analytical } \\
\text { Hierarchy } \\
\text { Process }\end{array}$ & $\begin{array}{l}\text { Hasil penelitian berupa } \\
\text { aplikasi sistempenilaian } \\
\text { kinerja dosen yang melibatkan } \\
\text { kriteria dan subkriteria. Pada } \\
\text { masing-masing kriteria dapat } \\
\text { ditentukan jumlah bobotnya } \\
\text { sehingga penilai dapat } \\
\text { memprioritaskan bobot yang } \\
\text { dirasa penting. }\end{array}$ \\
\hline
\end{tabular}

\section{LANDASAN TEORI}

\subsection{Sistem Pendukung Keputusan}

Sistem Pendukung Keputusan (SPK) merupakan sistem informasi interaktif yang menyediakan informasi, pemodelan, dan pemanipuasian data. Sistem Pendukung Keputusan digunakan untuk membantu pengambilan keputusan dalam situasi yang semiterstruktur dan situasi yang tidak terstruktur (Kusrini, 2007).[4] Pada dasarnya Sistem Pendukung Keputusan ini merupakan pengembangan lebih lanjut dari system informasi manajemen terkomputerisasi yang dirancang sedemikian rupa sehingga bersifat interaktif dengan pemakainya. Sifat interaktif ini dimaksudkan untuk memudahkan integrasi antara berbagai komponen dalam proses pengambilan keputusan seperti 
prosedur, kebijakan, teknik analisis serta pengalaman dan wawasan manajerial guna membentuk suatu kerangka keputusan yang bersifat fleksibel. Sistem Pendukung Keputusan terdiri dari tiga komponen utama atau subsistem yaitu :

1. Subsistem Data (Data Subsystem)

2. Subsistem Model (Model Subsystem)

3. Subsistem Dialog (User System Interface)

\subsection{Simple Additive Weighting}

Metode Simple Additive Weighting (SAW) sering juga dikenal istilah metode penjumlahan terbobot. Konsep dasar metode SAW adalah mencari penjumlahan terbobot dari rating kinerja pada setiap alternative pada semua atribut (Fishburn, 1967) (MacCrimmon, 1968).[5] Metode SAW membutuhkan proses normalisasi matriks keputusan (X) ke suatu skala yang dapat diperbandingkan dengan semua rating alternative yang ada. Metode ini merupakan metode yang paling terkenal dan paling banyak digunakan dalam menghadapi situasi Multiple Attribute Decision Making (MADM). MADM itu sendiri merupakan suatu metode yang digunakan untuk mencari alternative optimal dari sejumlah alternative dengan kriteria tertentu. Langkah-langkah dari metode SAW adalah :

1. Menentukan kriteria-kriteria yang akan dijadikan acuan dalam pengambilan keputusan, yaitu C.

2. Menentukan rating kecocokan setiap alternative pada setiap kriteria.

3. Membuat matriks keputusan berdasarkan kriteria (C), kemudian melakukan normalisasi matriks berdasarkan persamaan yang disesuaikan dengan jenis atribut (atribut keuntungan ataupun atribut biaya) sehingga diperoleh matriks ternormalisasi R.

4. Hasil akhir diperoleh dari proses perangkingan yaitu penjumlahan dari perkalian matriks ternormalisasi $\mathrm{R}$ dengan vector bobot sehingga diperoleh nilai terbesar yang dipilih sebagai alternative terbaik (A) sebagai solusi (Kusumadewi, 2006).

\section{METODE PENELITIAN}

\subsection{Metode Pengembangan Sistem}

Sistem Pendukung Keputusan Seleksi Karyawan dikembangkan menggunakan metode prototype. Dalam metode pengembangan tersebut terdapat beberapa tahapan yakni pengumpulan kebutuhan, perancangan dan evaluasi prototype. Pada tahap pengumpulan kebutuhan, peneliti dan klien menentukan data-data analisis yang dibutuhkan. Tahap Perancangan menjadi dasar pembuatan prototype. Pada tahap evaluasi prototype, hasil pengujian manual dan hasil pengujian sistem . Metode prototype merupakan metode yang membutuhkan waktu lebih cepat dalam pengembangan sistem.

\subsubsection{Pengumpulan Kebutuhan}

Data yang dibutuhkan dalam penelitian ini sebagai dasar dalam melakukan pengembangan sistem pendukung keputusan. Berikut data-data yang dibutuhkan dapat dilihat pada tabel 2.

Tabel 2. Data Penelitian

\begin{tabular}{|c|l|l|}
\hline No & Data yang dibutuhkan & \multicolumn{1}{|c|}{ Sumber Data } \\
\hline 1 & Data pelamar & $\begin{array}{l}\text { Dokumentasi dari Pimpinan Green } \\
\text { Advertising }\end{array}$ \\
\hline 2 & $\begin{array}{l}\text { Data kriteria penerimaan } \\
\text { karyawan baru }\end{array}$ & $\begin{array}{l}\text { Dokumentasi dari Pimpinan Green } \\
\text { Advertising }\end{array}$ \\
\hline 3 & Pembobotan Subkriteria & $\begin{array}{l}\text { Wawancara Pimpinan Green } \\
\text { Advertising }\end{array}$ \\
\hline
\end{tabular}




\subsubsection{Perancangan}

a. Diagram Konteks

Sistem Pendukung Keputusan ini digunakan oleh dua pengguna yaitu Admin dan Pelamar.

Admin menggunakan hak akses login, melakukan input data kriteria, data subkriteria dan proses hasil analisis. Pelamar mengajukan berkas lamaran.

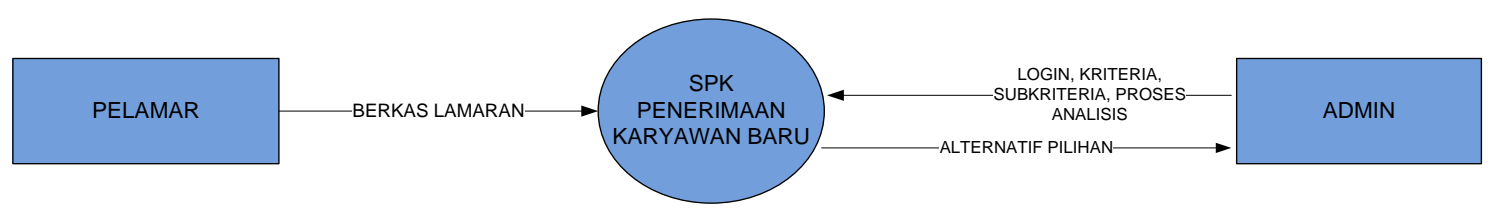

Gambar 1. Context Diagram

b. Data Flow Diagram

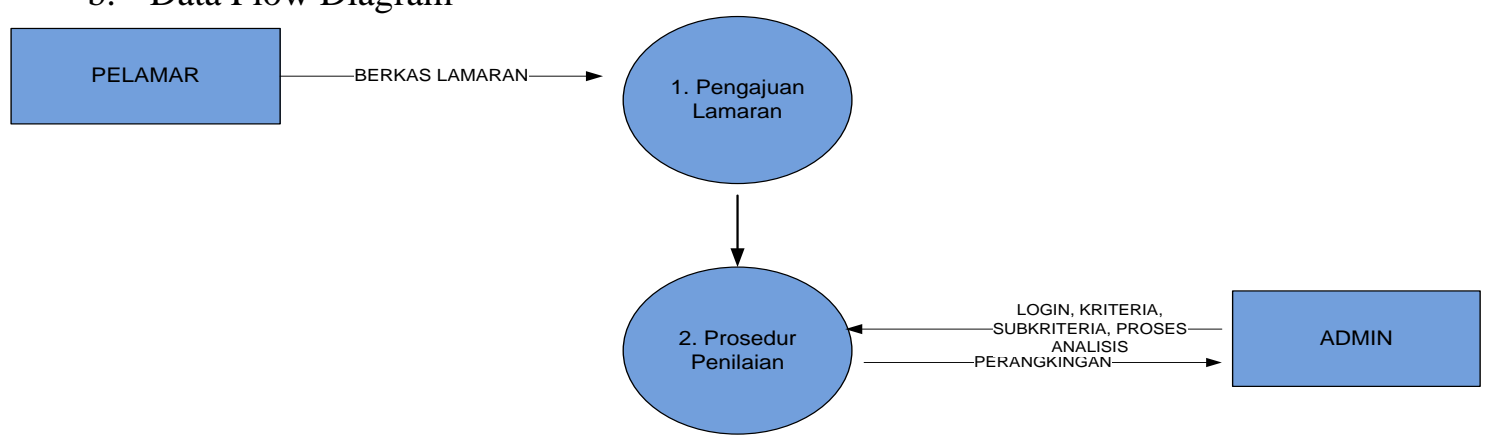

Gambar 2. DFD Level 0

\subsubsection{Evaluasi Prototype}

Pada tahap Evaluasi, dilakukan pengujian terhadap Sistem Pendukung Keputusan Penerimaan Karyawan Baru dengan membandingkan hasil perhitungan sistemdengan hasil perhitunganmanual. Pengujian ini dilakukan dengan menggunakan lima orang alternative.

\subsection{Metode Analisis Data menggunakan Metode SAW}

Metode SAW sering dikenal sebagai metode penjumlahan terbobot. Konsep dasar dari metode SAW adalah mencari penjumlahan terbobot dari rating kriteria pada setiap alternative pada semua atribut. Dalam Metode Simple Additive Weightingterdapat beberapa kriteria dan pembobotan nilai yang dibutuhkan untuk proses perhitungan. Kriteria dan pembobotan nilai yang digunakan oleh pimpinan Green Advertising selama penerimaan karyawan baru dapat dilihat pada tabel 3.

Tabel 3. Kriteria Pilihan

\begin{tabular}{|c|l|l|l|l|}
\hline No & Kode & Kriteria & Sub Kriteria & Bobot \\
\hline 1 & C1 & Pendidikan & SMA & 50 \\
& & terakhir & S1 & 80 \\
\hline 2 & C2 & Pengalaman kerja & Belum Pernah & 30 \\
& & & $<1$ tahun & 70 \\
& & & $>1$ tahun & 90 \\
\hline 3 & C3 & Keahlian & Tidak Ada & 20 \\
& & & Office & 70 \\
& & & Office dan Coreldraw & 80 \\
& & & Office dan Potoshop & 80 \\
& & & Office, Coreldraw dan Potoshop & 90 \\
\hline 4 & C4 & Kelengkapan & Tidak Lengkap & 50 \\
& & Berkas & Lengkap & 90 \\
\hline
\end{tabular}




\section{HASIL DAN PEMBAHASAN}

\subsection{Perhitungan dengan menggunakan Metode Simple Additive Weighting (SAW)}

Dari beberapa pelamar yang mengajukan lamaran di CV. Green Advertising diambil lima orangalternatif untuk penerapan metode Simple Additive Weighting (SAW) dalam penerimaan karyawan baru. Alternatif tersebut antara lain :

Tabel 4. Data alternatif

\begin{tabular}{|l|l|}
\hline Ai & Nama \\
\hline A1 & Megawati \\
\hline A2 & Nur Muslimah I. Yawu \\
\hline A3 & Moh. Fahrul \\
\hline A4 & Rahmat Hidayat \\
\hline A5 & Sri Wana \\
\hline
\end{tabular}

a. Membuat Rating Kecocokan pada alternatif

Dalam metode Simple Additive Weight tahap selanjutnya adalah normalisasi matriks keputusan X dengan cara menghitung nilai rating kinerja ternormalisasi (Rij) dari alternative (Ai) pada kriteria (Cj). Perhitungan dari rating kecocokan dapat dilihat pada tabel 5.

Tabel5. Rating Kecocokan Alternatif dan Kriteria

\begin{tabular}{|c|c|c|c|c|}
\hline \multirow{2}{*}{ Alternatif } & \multicolumn{4}{|c|}{ Kriteria } \\
\cline { 2 - 5 } & C1 & C2 & C3 & C4 \\
\hline A1 & 50 & 70 & 70 & 90 \\
\hline A2 & 50 & 70 & 80 & 90 \\
\hline A3 & 50 & 90 & 80 & 90 \\
\hline A4 & 50 & 70 & 80 & 90 \\
\hline A5 & 50 & 90 & 90 & 90 \\
\hline
\end{tabular}

Berdasarkan tabel 10 diatas, dapat dibentuk matrik keputusan X sebagai berikut :

$$
X=\left\{\begin{array}{llll}
50 & 70 & 70 & 90 \\
50 & 70 & 80 & 90 \\
50 & 90 & 80 & 90 \\
50 & 70 & 80 & 90 \\
50 & 90 & 90 & 90
\end{array}\right\}
$$

b. Menormalisasi matriks X menjadi matriks R berdasarkan persamaan (1)

Keterangan :

$$
\mathrm{r}_{\mathrm{ij}}=\left\{\begin{array}{l}
\frac{x_{i j}}{\operatorname{Max} x_{i j}} \\
\frac{\operatorname{Min} x_{i} x_{i j}}{x_{i j}}
\end{array} .\right.
$$

$\mathrm{r}_{\mathrm{ij}} \quad=$ Nilai rating kinerja ternormalisasi

$\mathrm{x}_{\mathrm{ij}} \quad=$ Nilai atribut alternatif yang dimiliki dari setiap kriteria

$\operatorname{Max}_{\mathrm{i}} \quad=$ Nilai terbesar

$\operatorname{Min}_{\mathrm{i}} \quad=$ Nilai terkecil

benefit $=$ Jika nilai terbesar adalah terbaik

cost $=$ Jika nilai terkecil adalah terbaik

1. Kriteria Pendidikan Terakhir termasuk atribut Benefit

$$
\begin{aligned}
& \mathrm{r}_{11}=\frac{50}{\operatorname{Max}(50 ; 50 ; 50 ; 50)}=\frac{50}{50}=1 \\
& \mathrm{r}_{21}=\frac{50}{\operatorname{Max}(50 ; 50 ; 50 ; 50)}=\frac{50}{50}=1
\end{aligned}
$$




$$
\begin{aligned}
& \mathrm{r}_{31}=\frac{50}{\operatorname{Max}(50 ; 50 ; 50 ; 50)}=\frac{50}{50}=1 \\
& \mathrm{r}_{41}=\frac{50}{\operatorname{Max}(50 ; 50 ; 50 ; 50)}=\frac{50}{50}=1 \\
& \mathrm{r}_{51}=\frac{50}{\operatorname{Max}(50 ; 50 ; 50 ; 50)}=\frac{50}{50}=1
\end{aligned}
$$

2. Kriteria Pengalaman Kerja termasuk atribut Benefit

$$
\begin{aligned}
& \mathrm{r}_{12}=\frac{70}{\operatorname{Max}\{70 ; 70 ; 90 ; 70 ; 90\}}=\frac{70}{90}=0,78 \\
& \mathrm{r}_{22}=\frac{70}{\operatorname{Max}\{70 ; 70 ; 90 ; 70 ; 90\}}=\frac{70}{90}=0,78 \\
& \mathrm{r}_{32}=\frac{90}{\operatorname{Max}\{70 ; 70 ; 90 ; 70 ; 90\}}=\frac{90}{90}=1 \\
& \mathrm{r}_{42}=\frac{70}{\operatorname{Max}\{70 ; 70 ; 90 ; 70 ; 90\}}=\frac{90}{90}=0,78 \\
& \mathrm{r}_{52}=\frac{90}{\operatorname{Max}\{70 ; 70 ; 90 ; 70 ; 90\}}=\frac{90}{90}=1
\end{aligned}
$$

3. Kriteria Keahlian termasuk atribut Benefit

$$
\begin{aligned}
& \mathrm{r}_{13}=\frac{70}{\operatorname{Max}\{70 ; 80 ; 80 ; 80 ; 90\}}=\frac{80}{90}=0,78 \\
& \mathrm{r}_{23}=\frac{80}{\operatorname{Max}\{70 ; 80 ; 80 ; 80 ; 90\}}=\frac{80}{90}=0,89 \\
& \mathrm{r}_{33}=\frac{80}{\operatorname{Max}\{70 ; 80 ; 80 ; 80 ; 90\}}=\frac{80}{90}=0,89 \\
& \mathrm{r}_{43}=\frac{80}{\operatorname{Max}\{70 ; 80 ; 80 ; 80 ; 90\}}=\frac{90}{90}=0,89 \\
& \mathrm{r}_{53}=\frac{90}{\operatorname{Max}\{70 ; 80 ; 80 ; 80 ; 90\}}=\frac{90}{90}=1
\end{aligned}
$$

4. Kriteria Kelengkapan Berkas termasuk atribut Benefit

$$
\begin{aligned}
& \mathrm{r}_{14}=\frac{90}{\operatorname{Max}\{90 ; 90 ; 90 ; 90 ; 90\}}=\frac{90}{90}=1 \\
& \mathrm{r}_{24}=\frac{90}{\operatorname{Max}\{90 ; 90 ; 90 ; 90 ; 90\}}=\frac{90}{90}=1 \\
& \mathrm{r}_{34}=\frac{90}{\operatorname{Max}\{90 ; 90 ; 90 ; 90 ; 90\}}=\frac{90}{90}=1 \\
& \mathrm{r}_{44}=\frac{90}{\operatorname{Max}\{90 ; 90 ; 90 ; 90 ; 90\}}=\frac{90}{90}=1 \\
& \mathrm{r}_{54}=\frac{90}{\operatorname{Max}\{90 ; 90 ; 90 ; 90 ; 90\}}=\frac{90}{90}=1
\end{aligned}
$$

Hasil normalisasi matriks $\mathrm{X}$ diperoleh matriks $\mathrm{R}$ sebagai berikut :

$$
R=\left\{\begin{array}{cccc}
1 & 0,78 & 0,78 & 1 \\
1 & 0,78 & 0,89 & 1 \\
1 & 1 & 0,89 & 1 \\
1 & 0,78 & 0,89 & 1 \\
1 & 1 & 1 & 1
\end{array}\right\}
$$

c. Melakukan proses perangkingan menggunakan persamaan (2)

$$
\mathrm{V}_{\mathrm{i}}=\sum_{j=1}^{n} w_{j} r_{i j}
$$

Keterangan :

$\mathrm{V}_{\mathrm{i}} \quad=$ Rating untuk setiap alternatif

$\mathrm{w}_{\mathrm{j}} \quad=$ Nilai bobot dari setiap kriteria

$\mathrm{r}_{\mathrm{ij}} \quad=$ Nilai rating kinerja ternormalisasi

Vector bobot $(\mathrm{W}) \quad:[0,14,0,29,0,36,0,21]$

$\mathrm{V}_{1}=(0,14)(1)+(0,29)(0,78)+(0,36)(0,78)+(0,21)(1)$

$=0,14+0,23+0,28+0,21$

$=0,86$ 


$$
\begin{aligned}
\mathrm{V}_{2} & =(0,14)(1)+(0,29)(0,78)+(0,36)(0,89)+(0,21)(1) \\
& =0,14+0,23+0,32+0,21 \\
& =0,9 \\
& =(0,14)(1)+(0,29)(1)+(0,36)(0,89)+(0,21)(1) \\
& =0,14+0,29+0,32+0,21 \\
& =0,96 \\
& =(0,14)(1)+(0,29)(0,78)+(0,36)(0,89)+(0,21)(1) \\
& =0,14+0,23+0,32+0,21 \\
& =0,9 \\
& =(0,14)(1)+(0,29)(1)+(0,36)(1)+(0,21)(1) \\
\mathrm{V}_{5} \quad & 0,14+0,29+0,36+0,21 \\
& =1
\end{aligned}
$$

Nilai terbesar ada pada $\mathrm{V}_{5}$ sehingga alternative $\mathrm{A}_{5}$ (Pelamar Kelima) adalah alternative yang terpilih sebagai alternatif terbaik. Berikut perangkingan untuk Calon Pelamar (lihat Tabel 6)

Tabel 6. Perangkingan untuk Calon Pelamar

\begin{tabular}{|c|c|c|c|c|c|}
\hline \multirow{2}{*}{ Alternatif } & \multicolumn{4}{|c|}{ Kriteria } & \multirow{2}{*}{ Hasil } \\
\cline { 2 - 5 } & $\begin{array}{c}\text { Pendidikan } \\
\text { Terakhir }\end{array}$ & $\begin{array}{c}\text { Pengalaman } \\
\text { Kerja }\end{array}$ & Keahlian & $\begin{array}{c}\text { Kelengkapan } \\
\text { Berkas }\end{array}$ & \\
\hline A1 & 0,14 & 0,23 & 0,28 & 0,21 & 0,86 \\
\hline A2 & 0,14 & 0,23 & 0,32 & 0,21 & 0,9 \\
\hline A3 & 0,14 & 0,29 & 0,32 & 0,21 & 0,96 \\
\hline A4 & 0,14 & 0,23 & 0,32 & 0,21 & 0,9 \\
\hline A5 & 0,14 & 0,29 & 0,36 & 0,21 & 1 \\
\hline
\end{tabular}

\subsection{Implementasi}

a. Menu Login

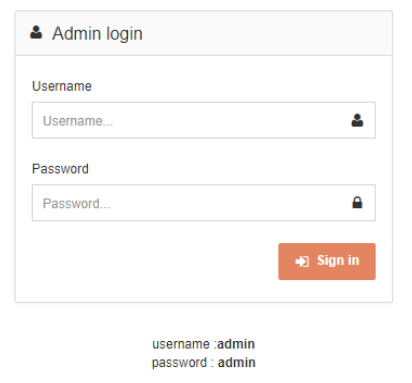

Gambar 4. Menu Login

b. Menu Utama

Pada halaman Menu Utama, terdapat 6 pilihan menu yang ditampilkan. Menu tersebut antara lain menu Pelamar, Menu Kriteria, Menu Subkriteria, Menu Klasifikasi dan Menu Analisa. 


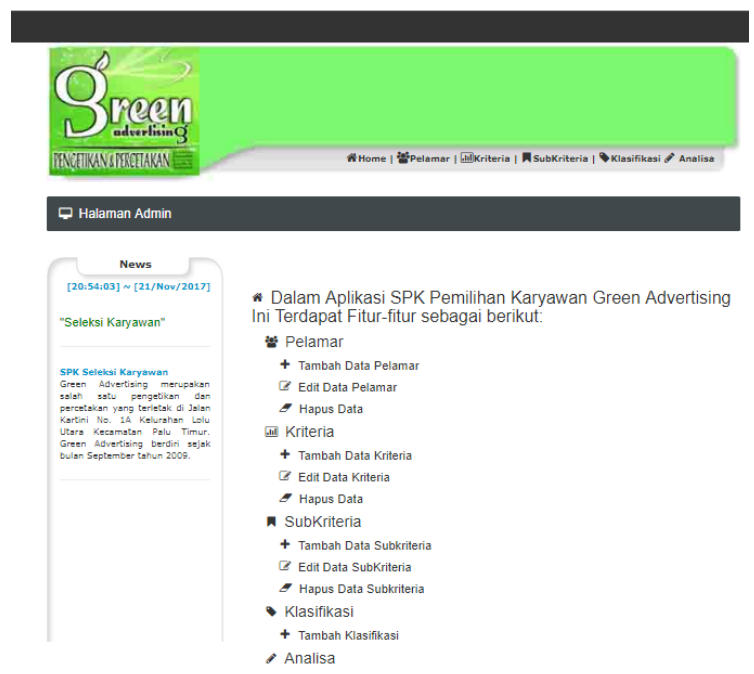

Gambar 5. Menu Utama

c. Form Kriteria

Pada menu form kriteria berisi informasi tentang kriteria yang digunakan beserta atribut yang digunakan.

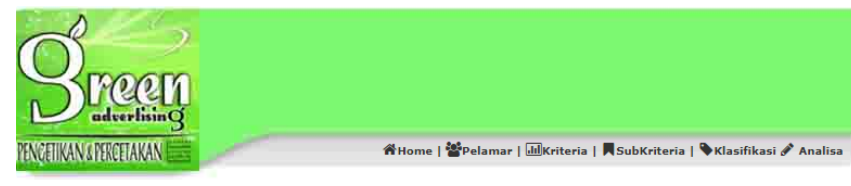

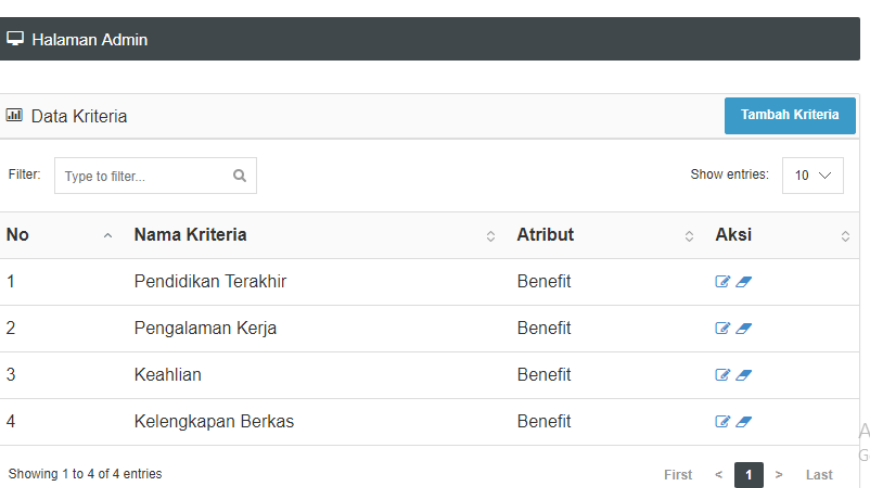

Gambar 6. Form Kriteria

d. Menu Klasifikasi

Menu klasifikasi merupakan penilaian data pelamar yang akan digunakan. Isi dari rincian klasifikasi tersebut adalah kriteria pendidikan terakhir, kriteria pengalaman kerja, kriteria keahlian dan kriteria kelengkapan berkas. 


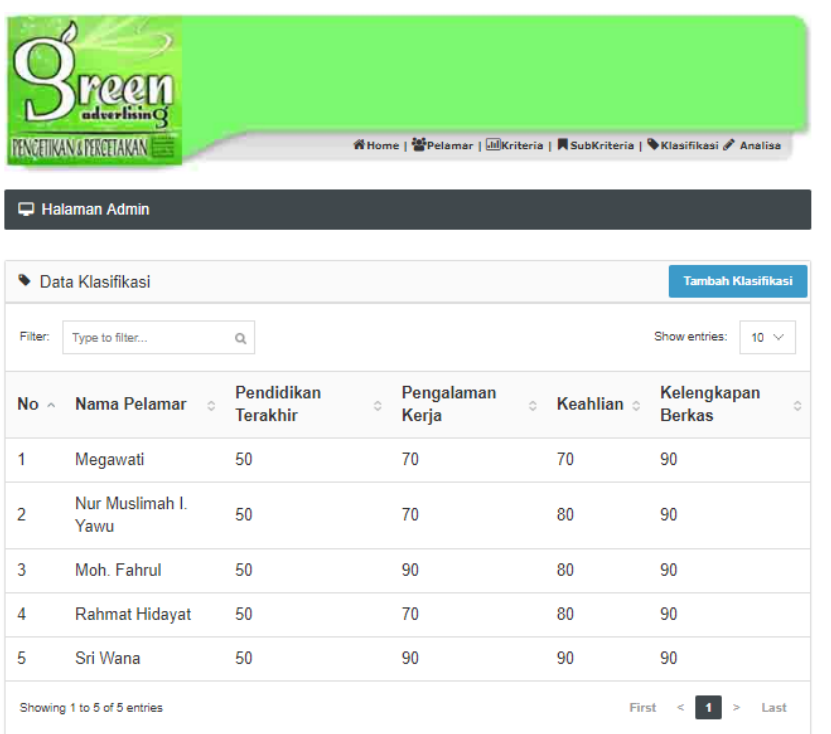

Gambar 7. Menu Klasifikasi

e. Hasil Analisa

Hasil dan proses perhitungan sistem ditampilkan dari tahap pembobotan, tahap normalisasi dan tahap perangkingan.

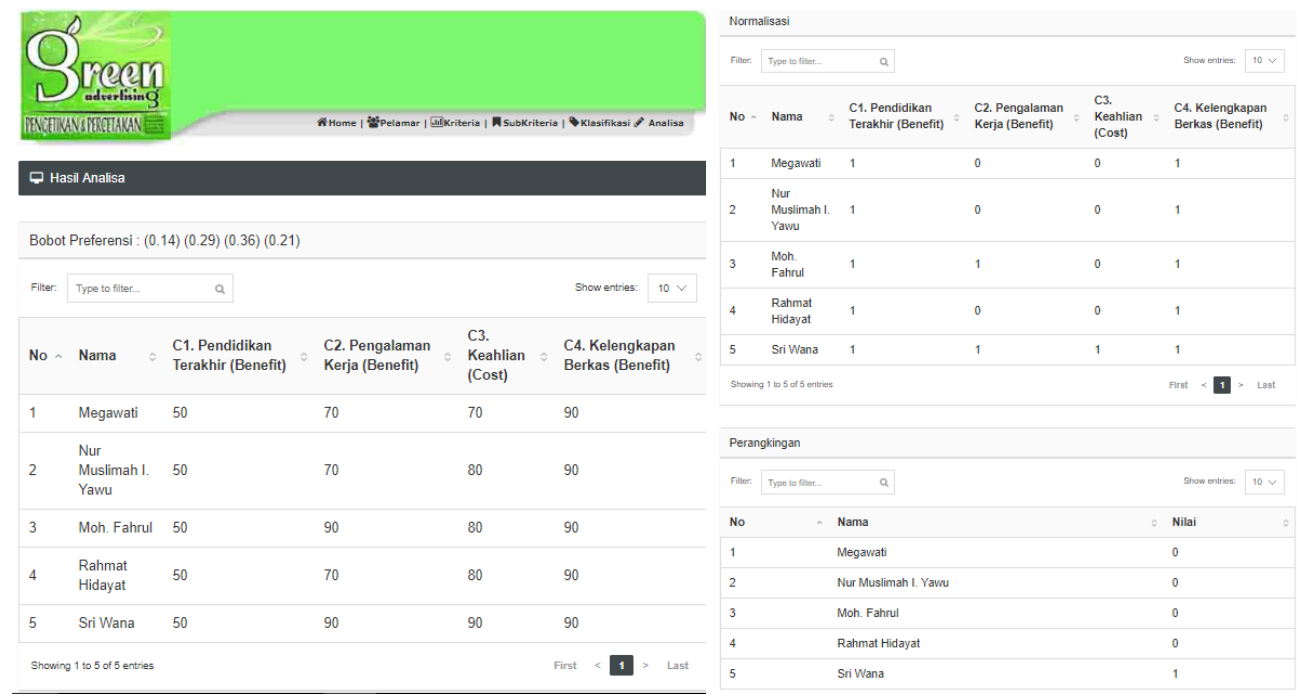

Gambar 8. Hasil Analisa

Dari proses perhitungan menggunakan sistem komputerisasi menghasilkan alternative pelamar kelima yang layak untuk dipilih dalam penerimaan karyawan. Jika dibandingkan dengan hasil perhitungan manual maka terdapat pilihan alternatif yang sama.

\section{KESIMPULAN}

Berdasarkan hasil dari perancangan dan implementasi metode Simple Additive Weighting (SAW) dalam penerimaan karyawan pada Green Advertising maka peneliti menarik kesimpulan sebagai berikut :

a. Informasi yang ditampilkan dalam sistem adalah nilai dari alternatif. Nilai yang tertinggi dari alternatif merupakan pilihan calon karyawan terbaik.

b. Perhitungandengan menggunakan metode simple additive weighting (SAW) memiliki hasil yang sama dengan perhitungan manual 
c. Hasil dari proses menggunakan metode simple additive weighting (SAW) menjadi penunjang pendukung keputusan pimpinan dalam penerimaan karyawan pada Green Advertising

\section{SARAN}

Adapun saran yang diberikan peneliti adalah sebagai berikut :

a. Pengembangan aplikasi ini masih menggunakan bahasa pemrograman PHP dan MySQL, untuk pengembangan selanjutnya bisa digunakan bahasa pemrograman lainnya sebagai bahan perbandingan penelitian.

b. Sistem pendukung keputusan penerimaan karyawan dapat menggunakan metode lainnya sebagai bahan perbandingan untuk pengembangan penelitian selanjutnya.

\section{Ucapan Terima Kasih}

Peneliti mengucapkan terima kasih kepada STMIK Adhi Guna yang telah memberi dukungan financial terhadap penelitian ini.

\section{Daftar Pustaka}

[1] Kusumadewi, dkk. 2006. Fuzzy Multi-Attribute Decision Making (Fuzzy MADM). Graha Ilmu, Yogyakarta.

[2] Hermanto, Nandang (2012) Sistem Pendukung Keputusan Menggunakan Metode Simple Additive Weighting (Saw) Untuk Menentukan Jurusan Pada Smk Bakti Purwokerto. Semantik 2012. pp. 52-62.

[3] Ari Jayanti, N.D. (2016). Implementasi Metode SAW dan AHP Pada Sistem Informasi Penilaian Kinerja Dosen. CSRID Journal, 86-98.

[4] Kusrini. 2007. Konsep dan Aplikasi Sistem Pendukung Keputusan. Penerbit Andi,. Yogyakarta.

[5] Fishburn, P., C., 1967, Additive Utilities with Incomplete Product Set : Application to Priorities and Assigments, Operations Research Society of America (ORSA), Baltimor, MD, U.S.A. 